\title{
Oxidative stress, advanced glycation end products and residual renal function in the rat model of unilateral ureteral obstruction: effects of phlogenzym and losartan
}

\author{
K. Sebekova, Jr., P. Blazicek ${ }^{1}$, D. Syrova ${ }^{2}$, S. Galbavy ${ }^{3}$, R. Schinzel ${ }^{4}$,
} A. Heidland ${ }^{4}$, K. Sebekova ${ }^{5}$

St. Elisabeth and Barbara Hospital

5, Mauerstraße, Halle/Saale, Germany, 06110

${ }^{1}$ Alpha Medical

49, Vlcie hrdlo, Slovakia, 81207

${ }^{2}$ Children Hospital

1, Limbova, Bratislava, Slovakia, 83340

${ }^{3}$ St. Elisabeth University of Health and Social Sciences

1, Namestie, maja, Bratislava, Slovakia, 81100

${ }^{4}$ University of Wurzburg

6, Oberdurrbacher Straße, Wurzburg, Germany, 97080

${ }^{5}$ Slovak Medical University

12, Limbova, Bratislava, Slovakia, 83303

katarina.sebekova@szu.sk

\begin{abstract}
Aim. Oxidative stress plays a role in the pathogenesis of ureteral obstruction. Methods. We studied parameters of oxidative status, levels of advanced glycation end products (AGEs), and contralateral (CL) kidney function in the rat model of unilateral ureteral obstruction (UUO). The effect of Phlogenzym (12 $\mathrm{mg} /$ day orally); losartan $(20 \mathrm{mg} / \mathrm{l}$ in drinking water $)$, and their combination was studied. Results. In placebo-administered UUO rats AGEs and malondialdehyde levels were higher than in the sham operated controls. Function of the CL kidney was slightly impaired, its collagen content and protein/deoxyribonucleic acid ratio (P/DNA) in the glomeruli increased. All treatments prevented the rise in collagen content, $P / D N A$ ratio, and improved CL kidney function. Phlogenzym ameliorated lipid peroxidation and AGE levels. Conclusions. In the model of UUO systemically increased oxidative stress may play a role in development of tubulointerstitial fibrosis and in the functional impairment of the CL kidney. Suppression of the oxidative stress and blockade of angiotensin-1 receptors might mitigate the progression of obstructive uropathy.
\end{abstract}

Keywords: ureteral obstruction, advanced glycation end products, oxidative stress, malondialdehyde, collagen.

Introduction. In the model of unilateral ureteral obstruction (UUO) altered hemodynamics, hypoxia, infiltration with macrophages, up-regulated renin-angiotensin-aldosterone system producing vasoactive com-

(C) Institute of Molecular Biology and Genetics NAS of Ukraine, 2010 pounds, result in tubulointerstitial fibrosis of the ligated kidney [1-3]. Angiotensin (Ang) II may promote cell growth and fibrosis via overexpression of growth factors and cytokines, and the induction of oxidative stress [4]. The latter one is in the tubulointerstitium of obstructed kidney reflected by 
increased heme oxygenase-1 expression, accumulation of $\mathrm{N}^{\varepsilon}$-(carboxymethyl)lysine (CML), and perturbation of tubular antioxidants; and systemically by the rise in plasma malondialdehyde (MDA) levels $[5,6]$. The enhanced formation of reactive oxygen species (ROS) may exert toxic effects in other tissues and organs. The contralateral (CL) kidney, due to its compensatory hypertrophy, might be the most susceptible.

Advanced glycation end products (AGEs) are formed on proteins by non-enzymatic glycation and/or glycoxidation. With decreased renal function they accumulate in tissues and circulation, due to retention and enhanced synthesis under exaggerated oxidative- and carbonyl-stress [7, 8]. Interaction of AGEs with their specific cell surface receptor RAGE leads to the production of ROS, which accelerate formation of AGEs [9]. Experimental studies suggest the interaction between the AGE-RAGE and the renin-angiotensin systems [10]. In vitro, Ang II receptor 1 blockers (ARBs) lower AGEs formation, and suppress the AGEsinduced enhanced Ang 1 receptor protein [11, 12]. They also attenuate the accumulation of AGEs in vivo $[13,14]$.

In studies on pig proximal tubular cells (LLC-PK1) trypsin prevented the AGEs-induced cell hypertrophy and accumulation of AGEs [15, 16]. In rodents administration of proteases improved the course of various renal diseases $[17,18]$. Whether administration of proteases interferes with AGEs and oxidative stress in vivo remains unclear.

We investigated the possible involvement of the systemically enhanced oxidative stress in relation to the function and structure of the CL kidney, in the model of UUO. AGE-lowering- and antioxidant-potential of the above mentioned treatment modalities, and their combination was studied.

Materials and methods. The trial was conducted according to the guidelines for studies using laboratory animals, after the approval by the local Ethics Board for Experimental Animals (Bratislava).

Rats. Male Wistar rats (180-220 g, VELAS Praha, Czech Republic) were caged under controlled humidity, temperature, and light/dark cycle, with free access to drinking water and food (SP1, Top Dovo, Czech Republic). After induction of UUO rats were pair-fed to the UUO placebo administered group.
Induction of unilateral ureteral obstruction. Forty rats were subjected to UUO in i. p. thiopental narcosis. Briefly, right ureter was liberated, ligated twice with sterile silk, and cut between two ligations. Six shamoperated rats served as controls (CTRL).

Experimental protocol. UUO rats were randomized into 4 groups per 10 animals, administered during 14 days: a) placebo (UUO-P); b) a fixed mixture of proteases (UUO-E, Phlogenzym, «MUCOS Pharma», Germany) in a dose of $12 \mathrm{mg} /$ day in $1 \mathrm{ml}$ of tap water (each dose contained $2.42 \mathrm{mg}$ trypsin, $4.54 \mathrm{mg}$ bromelain, and $5.04 \mathrm{mg}$ flavonoid rutosid); c) ARB (UUO-ARB, Losartan, MSD, USA, $20 \mathrm{mg} / \mathrm{l}$ in drinking water); d) combined treatment (UUO-COMB, both drugs in the above mentioned dosage). Control and UUO-P rats were gavaged by $1 \mathrm{ml}$ of water.

Body weight and blood pressure (tail plethysmography) was recorded. At sacrifice (thiopental narcosis), blood was sampled from abdominal aorta and urine from bladder. Standard blood chemistry was determined (Vitros 250 analyzer, «J\&J», USA). Plasma or whole blood was stored at $-70^{\circ} \mathrm{C}$ for determination of: total antioxidant status (TAS) and glutathione peroxidase activity (GPX), («Randox», UK); plasma MDA [19] and lipofuscin (LF) [20] concentrations; and AGE specific fluorescence [21]. CML concentration was quantified with competitive ELISA using monoclonal antibodies according to the method developed by «Roche Diagnostika», Germany. One AGE unit (U) represented $50 \%$ reduction in binding. Proteinuria was determined by a pyrogallol red method.

Kidneys were weighed. Collagen content in renal cortex was determined in formaline fixed paraffin embedded slices, stained with hematoxilyne/eosine and Van Gieson. The contrast red area stained as collagen was expressed in per cent of the cortical tissue area with aids of computerized video camera. In glomeruli isolated by differential sieving method [22] the DNA [23] and protein content [24] was determined.

Statistics. The data were tested for normality and equality of variance, and compared either by one-way analysis of variance (ANOVA) with post hoc Scheffe's test; or by Kruskal-Wallis with Mann-Whitney $U$-tests. Results are given as mean $\pm \mathrm{SD}$, or as median, mean \pm SD (not normally distributed data); $\mathrm{p}<0.05$ was considered significant. 


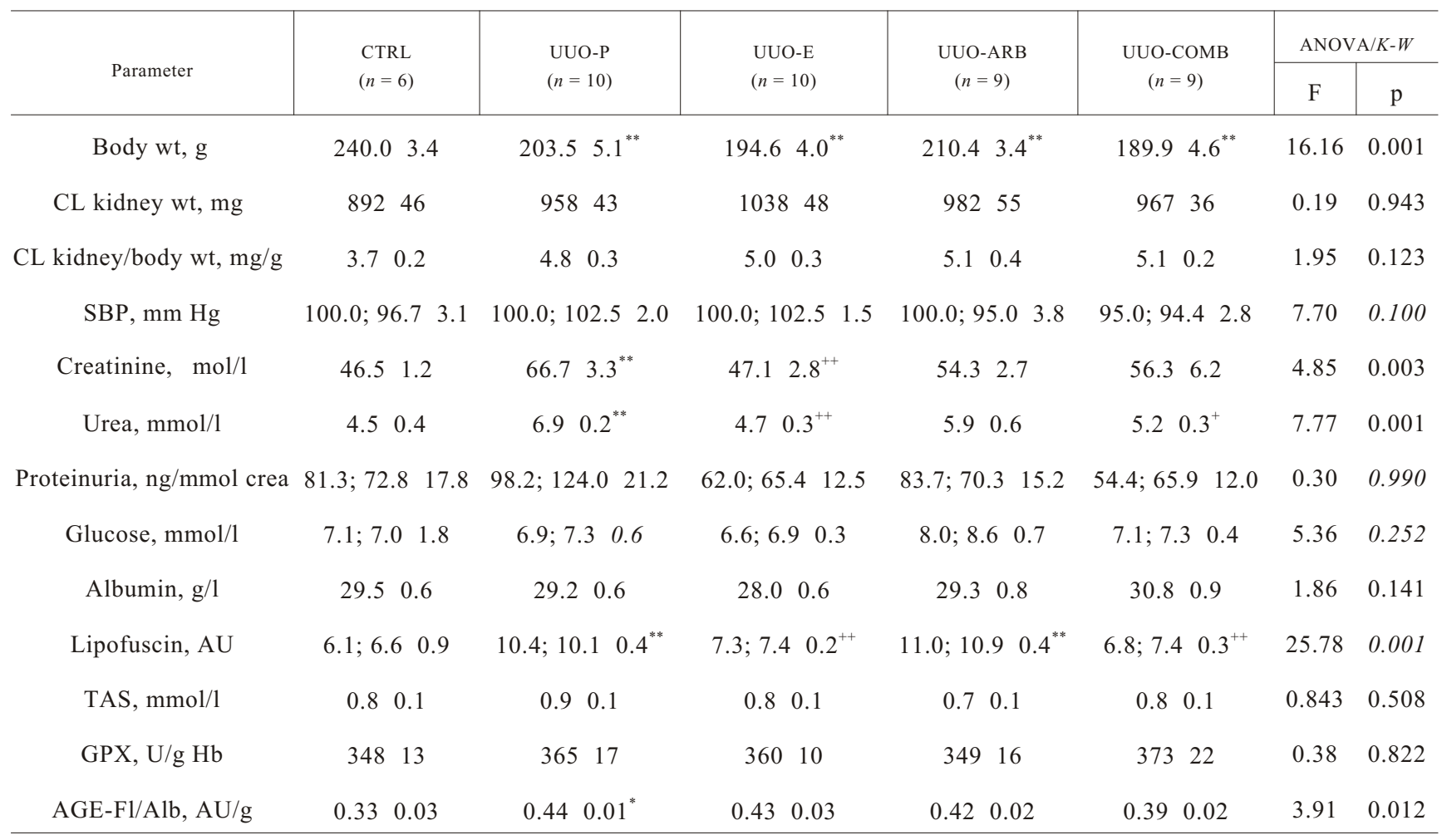

CTRL - sham operated control rats; UUO - unilateral ureteral obstruction; P - placebo; E - Phlogenzym; ABR - losartan; COMB combined treatment with E + ABR; ANOVA - one-way analysis of variance; K-W - Kruskal-Wallis test (in italics); wt - weight; SBP systolic blood pressure; CL: contralateral; crea: creatinine; MDA: malondialdehyde; AU: arbitrary units; TAS: total antioxidant status; GPX - glutathione peroxidase activity; $\mathrm{U}$ - units; $\mathrm{Hb}$ - hemoglobin; AGE-F1 - advanced glycation end products specific fluorescence; Alb albumin; ${ }^{*} \mathrm{p}<0.05$ vs. CTRL; ${ }^{*} \mathrm{p}<0.01$ vs. CTRL; $+-\mathrm{p}<0.05$ vs. UUO-P; $++-\mathrm{p}<0.01$ vs. UUO-P.

Results and discussion. Role of accumulation of AGEs in pathogenesis of UUO (Table). At sacrifice the body weight of the UUO-P rats was lower than that of CTRL rats. The weight of the CL kidney and kidney/body weight ratio was comparable. UUO resulted in hypertrophy of the glomeruli in CL kidney, as indicated by rise of protein/DNA ratio (Fig. 1, a). In LLC-PK1 cells, AGE-modified albumin induced cell hypertrophy via stimulation of protein synthesis and inhibition of its degradation [15, 16]. The latter one was, at least partially, caused by the decline in lysosomal cathepsin activity, due to down-regulation of mRNA levels [25]. Plasma AGEspecific fluorescence (Table) and CML concentrations (Fig. 2) were significantly higher in the UUO-P rats than in the CTRL, but not on the account of plasma albumin or glucose concentration. AGEs rose despite only a moderate changes in plasma creatinine levels. The rise in protein content of isolated glomeruli may be causally linked to enhanced circulating AGE levels, as supported by a direct relation between plasma CML and P/DNA content $(r=0.567, \mathrm{p}<0.02)$.

In the cortex of CL kidney collagen content increased 5-fold (Fig. 1, b). Incubation of LLC-PK1 or immortalized human kidney epithelial cells (IHKECs) with AGEmodified BSA results in intracellular accumulation of AGEs, associated with the induction of pro-fibrotic factors (overexpression of TGF- $\beta 1$ mRNA, rise in TGF- $\beta 1$ protein, enhanced activation of protein kinase $\mathrm{C}$, and fibronectin synthesis) $[12,15,16]$. Thus, elevated circulating AGEs may contribute to rise in renal cortex collagen content, as supported by a direct relation between plasma CML and renal cortex collagen content $(r=$ $=0.918, \mathrm{p}<0.001)$. However, in the UUO model plasma CML accumulates in spite of its enhanced renal excretion (Fig. 2). UUO represents a nonproteinuric model of 

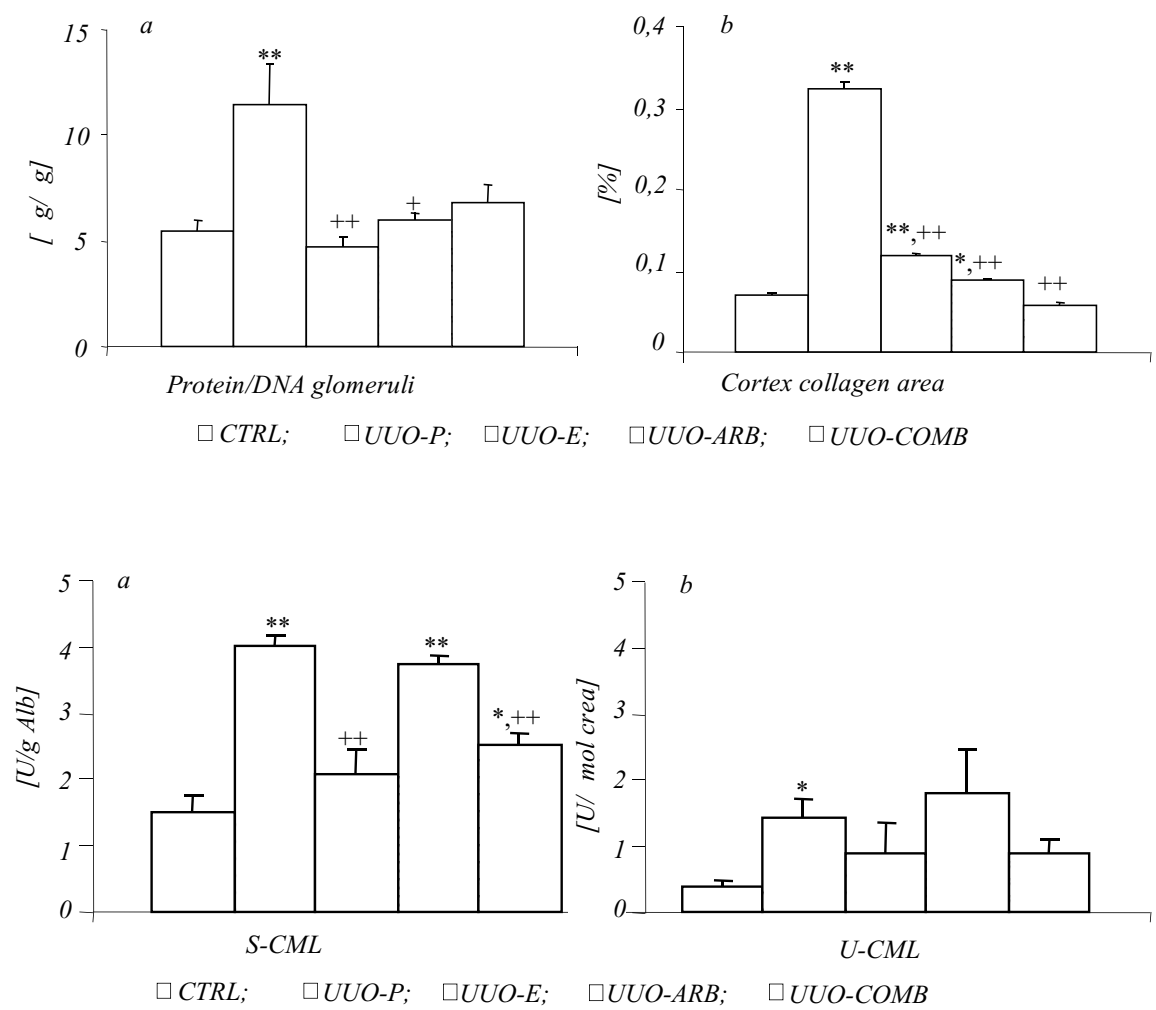

Fig. 1. Effects of UUO, and treatment with Phlogenzym, losartan, and their combination on contralateral kidney: $a$ - protein to DNA ratio in isolated glomeruli; $b$ - renal cortex collagen content. CTRL - sham operated controls; $U U O$ - unilateral ureteral obstruction; $P$ - placebo; $E$ - Phlogenzym; $A R B$ - losartan; $C O M B$ - combined treatment with $E+A B R ; * \mathrm{p}<0.05$ vs. CTRL; $* * \mathrm{p}$ $<0.01$ vs. CTRL; $+-\mathrm{p}<0.05$ vs. UUO-P; $++-\mathrm{p}<0.01$ vs. UUO-P
Fig. 2. Plasma levels and urinary excretion of $\mathrm{N}^{\varepsilon}$-(carboxymethyl)lysine (CML): $a-\mathrm{S}$ CML; $b$ - U-CML. CTRL - sham operated controls; UUO - unilateral ureteral obstruction; $P$ - placebo; $E$ - Phlogenzym; $A R B$ - losartan; $C O M B$ - combined treatment with $E+A B R ; A l b$ - albumin; crea creatinine interstitial fibrosis. Thus, a predominant excretion of AGE-modified peptides is anticipated. Their enhanced filtration load might also contribute to the damage of tubule cells with subsequent development of tubulointerstitial fibrosis.

Role of enhanced oxidative stress in pathogenesis of UUO (Table). Fourteen days after the induction of UUO oxidative stress was systemically enhanced, as reflected by increased MDA and lipofuscin levels. CML is considered as integrative biomarker of the cumulative protein damage induced by glycoxidation [26]. Much faster accumulation of CML than that of fluorescent AGEs, and high correlation between CML and MDA $(r=0.599, \mathrm{p}<0.05)$, or CML and LF concentrations $(r=0.556, \mathrm{p}<0.05)$, support the role of the oxidative stress in CML formation. Since the total antioxidant status and GPX activity were not altered, the enhanced oxidative stress seemed to result from overproduction of ROS, not caused by a compromised antioxidant defense. Shortly (12 h) after the onset of UUO heme oxygenase-1 activity increases, with a time dependent decline within the next 7 days [5]. It might not be excluded that during the early phase of UUO, enhanced production of ROS induces antioxidant enzyme activity, which returns to normal values, or even decreases, later.

Although the function of the CL kidney was only slightly altered, both plasma AGE-specific fluoresce, as well as CML levels correlated highly with those of serum creatinine $(r=0.560, \mathrm{p}<0.05$, and $r=0.760, \mathrm{p}<$ $<0.001$, respectively), indicating the important role of the kidney in their removal, and the role of oxidative stress in the impairment of renal function.

Effects of the treatment. We compared the established beneficial effects of the administration of losartan with the potential beneficial action of Phlogenzym and their combination on the function of the CL kidney, from the point of interference with AGEs and oxidative status, since: 1) inhibitors of converting enzyme and ARBs ameliorate the alterations induced by UUO [27]; 2) the experimental and clinical data suggest that ARBs may attenuate oxidative stress and formation of AGEs $[13,28,29]$; 3) proteolytic enzymes antagonize the AGE-induced toxicity in various renal cell cultures $[15$, 
16], and in models of progressive renal diseases administration of Phlogenzym exerted beneficial effects of on renal function and morphology $[17,18]$.

Contralateral kidney (Table). Administration of Phlogenzym, losartan or their combination to UUO rats resulted in comparable improvement of the CL kidney function, although significant decline in plasma creatinine concentration was reached only in UUO-E group. Urea accumulation was ameliorated in UUO-E and UUO-COMB groups. Treatment did not affect proteinuria, the body weight, CL kidney weight, or kidney/body weight ratio. All treatment modalities ameliorated renal cortex collagen accumulation (Fig. $1, b$ ). In all treated groups glomerular protein/DNA ratio was lower than in the UUO-P rats, reaching significance in the UUO-E and UUO-ARB groups (Fig. 1, a). Glomerular protein/DNA ratio correlated with plasma CML level $(r=0.458, \mathrm{p}<0.01)$. These data correspond with our previous findings in in vitro studies. In LLC-PK1 cells trypsin inhibited the AGE-induced cell hypertrophy, overexpression of TGF- $\beta 1$ mRNA, total TGF- $\beta 1$ protein, and increased AGE accumulation $[15,16]$. The above mentioned AGE-induced effects, as well as activation of protein kinase $\mathrm{C}$ and enhanced fibronectin synthesis were diminished also by co-incubation with losartan in IHKECs and LLC-PK1 cells [12]. Thus, interference of both, proteases and ARB with TGF- $\beta 1$, may in vivo result in attenuation hypertrophy, and of collagen accumulation.

Oxidative status (Table) and AGEs. Phlogenzym significantly ameliorated the rise in MDA. Lipofuscin levels remained elevated under treatment with $A R B$, pointing to a shift of lipid peroxidation towards secondary products. The antioxidant defense (TAS and GPX activity) was not influenced by any of the interventions. AGE-specific fluorescence was not influenced significantly by either treatment. Plasma CML levels were ameliorated by the administration of Phlogenzym alone or in combination with ABR. Urinary excretion of CML remained elevated in the UUO-ARB group (Fig. 2). Changes in CML levels observed under the treatment were not on the account of blood pressure, plasma albumin, or glucose concentrations. Potential involvement of oxidative events is supported by tight relationship between CML and MDA $(r=0.519, \mathrm{p}<0.001)$, or CML and LF concentrations $(r=0.755, \mathrm{p}<0.001)$.
Thus, partial persistence of enhanced oxidative stress under treatment with ARB was further reflected by elevated CML levels, despite of only a mild rise in plasma creatinine, and substantial increase in urinary CML excretion. At first glance this data are contradictory to our previous observation, in which the 12weeks-long administration of losartan to subtotally nephrectomized rats completely prevented the rise in plasma AGE levels [13]. However, in both studies losartan significantly increased urinary AGE excretion. We suppose that in spite of enhanced renal excretion longer time is needed to normalize the elevated circulating AGE levels. Moreover, it is equivocal whether the sub-antihypertensive dose of losartan administered in our study is sufficient to block the oxidative stress induced by Ang II. In the rat model of congestive heart failure, an increase in antioxidant defense and a decline in oxidative stress was achieved after administration of a 100-fold higher dose of losartan [29]. Losartan effectively prevented glomerular hypertrophy and collagen accumulation, despite persistent oxidative stress and elevated AGE levels. ARBs were capable to reduce the expression of RAGE in human endothelial cells, and to modify the AGE-RAGE interaction by suppression of RAGE expression in the type 2 diabetic KK/Ta mice $[11,30]$. We suppose that suppression of RAGE under ARB treatment may to measurable extent prevent progressive renal damage even under the persisting oxidative stress.

Phlogenzym attenuated accumulation of AGEs and lipid peroxidation products. CML adducts are one of the most relevant ligands for RAGE and mediate NF$\kappa \mathrm{B}$ pathways, resulting in intracellular generation of ROS $[9,31]$. In in vitro studies proteases could inactivate the extracellular domain of the RAGE, thus interfere directly with production of ROS, decreasing formation of AGEs and lipid peroxidation products [15, 16]. However, in Phlogenzym, rhutosid is added as antioxidant to stabilize trypsin and bromelain. In vitro, antioxidants ameliorate the toxic effects induced by AGEs [28]. According to our knowledge no data are available on the antioxidant/anti-AGE effects of rhutosid. However, water-soluble rutin derivative suppressed in vitro glycation in tissue proteins [32]. Thus, the observed mechanisms of beneficial effects of Phlogenzym are to be interpreted with caution. 
Combined treatment showed additive effects and partially prevented the changes under ARB treatment, suggesting different mechanisms of the beneficial effects on CL kidney function of enzymes or ARBs.

Conclusions. Our study confirms the role of systemically enhanced oxidative stress in UUO, as reflected by increased plasma malondialdehyde, lipofuscin, CML and fluorescent AGE levels. Enhanced oxidative stress may be involved not only in the development of tubulointerstitial fibrosis of the ligated kidney, but also in impairment of the CL kidney. Suppression of oxidative stress and glycoxidation might therefore be of clinical relevance in retardation of the progression of renal disease.

Acknowledgements. Support from the Verein zur Bekampfung der Hochdruck- und Nierenkrankheiten, Wurzburg e. V., Germany, and an excellent help of Mr. Andre Klassen in preparation of the manuscript is acknowledged.

\section{К. Дж. Шебекова, П. Блажичек, Д. Сирова, Ш. Галбаві, А. Хейдланд, К. Шебекова}

Оксидативний стрес, кінцеві продукти глікації та залишкове функціонування нирки на моделі щурів з унілатеральною обструкцією сечоводу: ефекти флогензиму та лосартану

Резюме

Мета. Оксидативний стрес відіграє значну роль у патогенезі обструкиії сечоводу. Мета роботи полягала у вивченні параметрів оксидативного статусу, оцінюванні рівня кінцевих продуктів глікації $і$ функціонування контралатеральної нирки на моделі шурів з унілатеральною обструкиією сечоводу (УОС). Методи. На моделі УОС досліджували ефекти флогензиму (12 мг в день орально) і лосартану (20 мг/л у питній воді), а також їхньої комбінації. Результати. У щурів з УОС, які отримували плачебо, рівень накопичення кінцевих продуктів глікаціі та малондіальдегіду виявився вищим, ніж у несправжньооперованих контрольних щурів. Функціонування контралатеральної нирки незначно погіршилося, кониентрація колагену $і$ співвідношення вмісту білок/дезоксирибонуклеїнова кислота (P/ DNA) у клубочку нирки підвищені. Обробка досліджуваними лікарськими засобами запобігала збільшенню вмісту колагену, зростанню показника співвідношення P/DNA та покращувала функиіонування колатеральної нирки. Флогензим сприяв підвищенню рівня перекисного окиснення ліпідів та кінщевих продуктів глікації. Висновки. У моделі УОС систематичне збільшення оксидативного стресу може відігравати важливу роль у розвитку тубулоінтерстиційного фіброзу і порушенні функціонування контралатеральної нирки. Супресія оксидативного стресу та блокування рецептора ангіотензину-1 можуть послаблювати прогресію обструктивної уропатії.

Ключові слова: обструкція сечоводу, оксидативний стрес, малондіальдегід, колаген.
К. Дж. Шебекова, П. Блажичек, Д. Сырова, Ш. Галбави, А. Хейдланд, К. Шебекова

Оксидативный стресс, конечные продукты гликации

и остаточное функционирование почки на модели крыс с обструкцией мочеточника: эффекты флогензима и лосартана

Резюме

Цель. Оксидативный стресс играет значительную роль в патогенезе обструкиии мочеточника. Цель работь состояла в изучении параметров оксидативного статуса, оценке уровня конечных продуктов гликации и функционирования контралатеральной почки на модели крыс с унилатеральной обструкцией мочеточника (УОМ). Методи. На модели УОМ исследовали эффекты флогензима (12 мг в день орально) и лосартана (20 мг/л в питьевой воде), а также их комбинации. Результаты. У крыс с УОМ, получавших плачебо, уровень конечных продуктов гликачии и малондиальдегида оказался выме, чем у ложноооперованных контрольных крыс. Функционирование контралатеральной почки незначительно ухудшилось, конщентрация коллагена и соотношение содержания белок/дезоксирибонуклеиновая кислота (P/DNA) в клубочке почки повысились. Обработка исследуемыми лекарственными средставами предотвращала увеличение содержания коллагена, показателя соотношения P/DNA и улучшала функционирование колатеральной почки. Флогензим способствовал возрастанию уровня перекисного окисления липидов и конечных продуктов гликации. Выводы. В модели УОМ систематическое увеличение оксидативного стресса может быть причиной развития тубулоинтерстиционного фиброза и нарушения функционирования контралатеральной почки. Супрессия оксидативного стресса и блокирование рецептора ангиотензина-1 можгут ослаблять прогрессию обструктивной уропатии.

Ключевые слова: обструкиия мочеточника, оксидативный стресс, малондиальдегид, коллаген.

\section{REFERENCES}

1. Klahr S., Purkerson M. L. The pathophysiology of obstructive nephropathy: The role of vasoactive compounds in the hemodynamic and structural abnormalities of the obstructed kidney // Am. J. Kidney Dis.-1994.-23, N 2.-P. 219-223.

2. Diamond J. R., Kees-Folts D., Ding G., Frye J. E., Restrepo $N$. C. Macrophages, monocyte chemoattractant peptide-1, and TGF- $\beta 1$ in experimental hydronephrosis // Am. J. Physiol.-1994.- 266, N 6.-P. 926-933.

3. Kaneto H., Morrissey J., Klahr S. Increased expression of TGF- $\beta 1$ mRNA in the obstructed kidney of the rats with unilateral ureteral ligation // Kidney Int.-1993.-44, N 2.P. 313-321.

4. Klahr S., Morrissey J. J. The role of vasoactive compounds, growth factors and cytokines in progression of renal disease // Kidney Int.-2000.- 75, Suppl.-P. S7-14.

5. Kawada N., Moriyama T., Ando A., Fukunaga M., Miyata T., Kurokawa K., Imai E., Hori M. Increased oxidative stress in mouse kidneys with unilateral ureteral obstruction // Kidney Int.-1999.-56, N 3.-P.1004-1013.

6. Ricardo S. D., Ding G., Eufemio M., Diamond J. R. Antioxidant expression in experimental hydronephrosis: role of mechanical stretch and growth factors // Am. J. Physiol.-1997.272, N 6.-P. F789-798. 
7. Gugliucci A., Bendayan M. Renal fate of circulating advanced glycated end products (AGE): evidence for reabsorption and catabolism of AGE-peptides by renal proximal tubular cells // Diabetologia.-1996.-39, N 2.-P. 149-160.

8. Miyata T., Wada Y., Cai Z., Iida Y., Horie K., Yasuda Y., Maeda K., Kurokawa K., van Ypersele de Strihou C. Implication of an increased oxidative stress in the formation of advanced glycation end products in patients with end-stage renal failure // Kidney Int.-1997.-51, N 4.-P. 1170-1181.

9. Yan S. D., Schmidt A. M., Anderson G. M., Zhang J., Brett J., Zou Y. S., Pinsky D., Stern D. Enhanced cellular oxidant stress by the interaction of advanced glycation end products with their receptors/binding proteins // J. Biol. Chem.-1994.269, N 13.-P. 9889-9897.

10. Fujita M., Okuda H., Tsukamoto O., Asano Y., Hirata Y.L., Kim J., Miyatsuka T., Takashima S., Minamino T., Tomoike $H$., Kitakaze M. Blockade of angiotensin II receptors reduces the expression of receptors for advanced glycation end products in human endothelial cells. // Arterioscler. Thromb. Vasc. Biol.-2006.-26, N 10.-P. e138-142.

11. Miyata T., Van Ypersele de Strihou C., Ueda Y., Ichimori K., Inagi R., Onogi H., Ishikawa N., Nangaku M., Kurokawa K. Angiotensin II receptor antagonists and angiotensinconverting enzyme inhibitors lower in vitro the formation of advanced glycation end products: biochemical mechanisms // J. Am. Soc. Nephrol.-2002.-13, N 10.-P. 2478-2487.

12. Xiang G., Schinzel R., Munch G., Simm A., Sebekova K., Wanner $C$., Heidland A. Losartan suppresses the AGE-induced expression of TGF- $\beta 1$ in human tubule and LLC-PK1 cell lines // J. Am. Soc. Nephrol.-1999.-10, N 9.-P. 692A.

13. Sebekova K., Schinzel R., Munch G., Krivosikova Z., Dzurik $R$., Heidland A. Advanced glycation end product levels in subtotally nephrectomized rats: beneficial effects of angiotensin II receptor 1 antagonist losartan // Mineral. Electrol. Metab.-1999.-25, N 4-6.-P. 380-383.

14. Forbes J. M., Thomas M. C., Thorpe S. R., Alderson N. L., Cooper M. E. The effects of valsartan on the accumulation of circulating and renal advanced glycation end products in experimental diabetes // Kidney Int.-2004.-92.-S105-S107.

15. Xiang G., Schinzel R., Simm A., Sebekova K., Heidland A. Advanced glycated end products impair protein turnover in LLC-PK1 cells: amelioration by trypsin // Kidney Int.2001.-59, Suppl.-P. S53-S57.

16. Xiang G., Schinzel R., Simm A., Munch G., Sebekova K., Kasper M., Niwa T., Schmitz C., Heidland A. Advanced glycated end products (AGEs)-induced expression of TGF- $\beta 1$ is suppressed by a protease in the tubule cell line LLC-PK1// Nephrol. Dial. Transplant.-2001.-16, N 8.-P. 1562-1569.

17. Sebekova K., Dammrich J., Fierlbeck W., Krivosikova Z., Paczek L., Heidland A. Effects of chronic therapy with proteolytic enzymes on hypertension-induced renal injury in the model of Goldblatt hypertension // Am. J. Nephrol.-1998.18, N 6.-P. 570-576.

18. Sebekova K., Dammrich J., Krivosikova Z., Heidland A. The effects of oral protease administration in the rat remnant kidney model // Res. Exp. Med.-1999.-199, N 3.-P. 177-188.

19. Wong S. H., Knight J. A., Hopfer S. M., Zaharia O., Leack C. $N$., Jr., Sunderman F. W., Jr. Lipoperoxides in plasma as measured by liquid chromatographic separation of malondialdehyde-thiobarbituric acid adduct // Clin. Chem.-1987.- 33, N 2.-P. 214-220.
20. Tsuchida M., Miura T., Mizutani K., Aibara K. Fluorescent substances in mouse and human sera as a parameter of in vivo lipid peroxidation // Biochim. Biophys. Acta.-1985.- 834, N 2.-P. 196-204.

21. Muench G., Keis R., Wessels A., Riederer P., Bahner U., Heidland A., Niwa T., Lemke H. D., Schinzel R. Determination of advanced glycation end products in serum by fluorescence spectroscopy and competitive ELISA // Eur. J. Clin. Chem. Clin. Biochem.-1997.- 35, N 9.-P. 669-677.

22. Spiro R.G. Studies on the renal glomerular basement membrane: preparation and chemical composition // J. Biol. Chem.-1984.- 242, N 8.-P. 1915-1919.

23. Harris D.A. Fluorometric assay for DNA with Hoechst 33258 // Spectrophotometry and spectrofluorometryn / Eds D. A. Harris, C. L. Bashford.-Washington: IRL Press, 1987.P. 64-65.

24. Smith P. K., Krohn R. J., Hermanson G. T., Mallia A. K., Gartner F. H., Provenzano M. D., Fujimoto E. K., Goeke N. M., Olson B. J., Klenk D. C. Measurement of protein using bicinochonicinic acid // Anal. Biochem.-1985.-50, N 1.-P. 7685.

25. Sebekova K., Schinzel R., Ling H., Simm A., Xiang G., Gekle M., Munch G., Vamvakas S., Heidland A. Advanced glycated albumin impairs protein degradation in the proximal tubules cell line LLC-PK1 // Cell. Mol. Biol.-1998.-44, N 7.P. 1051-1060.

26. Brownlee $M$. Advanced protein glycosylation in diabetes and ageing // Annu. Rev. Med.-1995.-46.-P. 223-224.

27. Ishidoya S., Morrisey J., McCracken R., Klahr S. Angiotensin II receptor antagonist ameliorates renal tubulointerstitial fibrosis caused by unilateral ureteral obstruction // Kidney Int.-1995.-47, N 5.-P. 1285-1294.

28. Schupp N., Schinzel R., Heidland A., Stopper H. Genotoxicity of advanced glycation end products: involvement of oxidative stress and of angiotensin II type 1 receptors // Ann. N. Y. Acad. Sci.-2005.-1043.-P. 685-695.

29. Khaper N., Singal P. K. Modulation of oxidative by a selective inhibition of angiotensin II type 1 receptors in MI rats // J. Am. Coll. Cardiol.-2001.-37, N .-P. 1461-1466.

30. Fan Q., Liao J., Kobayashi M., Yamashita M., Gu L., Gohda T., Suzuki Y., Wang L. N., Horikoshi S., Tomino Y. Candesartan reduced advanced glycation end-products accumulation and diminished nitro-oxidative stress in type 2 diabetic KK/Ta mice // Nephrol. Dial. Transplant-2004.-19, N 12.P. 3012-3020.

31. Kislinger T., Fu C., Huber B., Qu W., Taguchi A., Du Yan S., Hofmann M., Yan S. F., Pischetsrieder M., Stern D., Schmidt A. M. N(epsilon)-(carboxymethyl)lysine adducts of proteins are ligands for receptor for advanced glycation end products that activate cell signaling pathways and modulate gene expression // J. Biol. Chem.-1999.-274, N 44.-P. 31740-31749.

32. Nagashawa T., Tabata N., Ito Y., Nishizawa N., Aiba Y., Kitts $D$. D. Inhibition of glycation reaction in tissue protein incubations by water-soluble rutin derivative // Mol. Cell. Biochem.-2003.-249, N 1-2.-P. 3-10.
UDC 616.61-008.6

Received 10.01.10 